\title{
Adjuvant! Online: Mind the Gap!
}

\author{
Adjuvant! Online: Pozor na rozdíly!
}

\author{
Kraft Rovere R. ${ }^{1}$, dos Santos Borges G. ${ }^{1,2}$, Staak Júnior M.C. ${ }^{2}$, Colchon P.H. ${ }^{2}$, Rebello J.R. ${ }^{2}$ \\ 'Oncology Unit, Santo Antonio Hospital, Blumenau, Santa Catarina, Brazil \\ 2 Universidade do Vale do Itajaí, Itajaí, Santa Catarina, Brazil
}

\section{Summary}

The objective of this study was to compare the actual outcome and prognosis estimated by the program Adjuvant! Online for breast cancer in Itajaí (Brazil). It is a retrospective cohort study, post-hoc analysis, in which 214 patients of three institutions were compared in real overall survival (OS) and disease-free survival (DFS) during a 3-year follow-up, and estimated OS and DFS with the program for 10 years by Adjuvant! Online, using the following variables: age, clinical stage, histological grade, lymph node involvement, immunohistochemical subtype and type of adjuvant therapy. The DFS and OS rates in the sample observed and estimated by the program demonstrated correspondence, with the curves trailing beneath the same pattern, due to shorter "real" follow-up ( 3 versus 10 years). The only group that demonstrated a marked decline in DFS in relation to the real prognosis was that of patients younger than 40 years.

\section{Key words}

breast neoplasms - chemotherapy - prognosis - survival analysis - Adjuvant! Online

\section{Souhrn}

Tato studie si klade za cíl porovnat skutečný výsledek a prognózu odhadovanou programem Adjuvant! Online pro rakovinu prsu v Itajaí (Brazílie). Je to retrospektivní kohortní studie, post-hoc analýza, ve které bylo porovnáno 214 pacientek ze tří institucí v několika kategoriích: reálné celkové přežití (OS) a disease-free survival (DFS) během třiletého sledování a předpokládané OS a DFS podle programu Adjuvant! Online na 10 let pomocí proměnných, jako jsou věk, klinické stadium, histologický grade, zasažení mízních uzlin, imunohistochemický subyp a typ použité adjuvantní terapie. Pravděpodobnosti přežití v parametrech DFS a OS, jak v př́padě reálných výsledků, tak výsledků odhadovaných programem, spolu korespondovaly a křivky přežití vykazovaly podobný směr, byt' se lišily s ohledem na rozdílnou dobu sledování pacientek (3 vs 10 let). Jediná skupina, která prokázala výraznější pokles DFS ve vztahu k reálné prognóze ve srovnání s předpokládánou, byla skupina pacientek mladších 40 let.

\section{Klíčová slova}

nádor prsu - chemoterapie - prognóza - analýza přežití - Adjuvant! Online
The authors declare they have no potential conflicts of interest concerning drugs, pruducts, or services used in the study.

Autoři deklarují, že $v$ souvislosti s předmětem studie nemají žádné komerční zájmy.

The Editorial Board declares that the manuscript met the ICMJE "uniform requirements" for biomedical papers.

Redakční rada potvrzuje, že rukopis práce splnil ICMJE kritéria pro publikace zasílané do biomedicínských časopisů.

Rodrigo Kraft Rovere, MD

Oncology Unit

Santo Antonio Hospital

Rua Itajai 545

Blumenau, Santa Catarina

CEP 89050100 Brazil

e-mail: rodrigorovere@hotmail.com

Submitted/Obdrženo: 8. 1.2013

Accepted/Príijato: 3. 2. 2013 


\section{Introduction}

Undoubtedly, breast cancer is one of the types of cancers that has benefited the most by exponential raising in the armamentarium of new drugs during the last decade [1-3]. Moreover, general use of adjuvant systemic therapy is most probably responsible, at least in part, for the reduction in cause-specific mortality from breast cancer in developed countries $[4,5]$.

Until recently, the only parameter used to decide about adjuvant therapy was the clinical judgment based on medical literature. The appearance of genetic prognostic and predictive signatures [6-8] has started to change the picture, even though the tests are far from being widely available, making it difficult to be used in daily practice.

Besides the genetic testing, a program (Adjuvant! Online) has been developed which estimates recurrence and benefit from adjuvant therapy based on clinical findings [9], validated in a population of North American women.

The validity of the Adjuvant! Online program and its applicability have been confirmed utilizing the breast cancer database of the British Columbia Cancer Agency (BCCA) [10]. Nevertheless, it has not been validated in a Latin American population, at least to our knowledge. The main aim of this study was to make a comparison between the risks estimated by the Adjuvant! Online and the real outcome in breast cancer patients in a Southern Brazilian population from Itajaí, Santa Catarina, which has its population largely composed of people with European genetic background, mainly of German and Italian origin.

We have performed a direct retrospective comparison in a cohort of 214 Southern Brazilian women regarding the Adjuvant! Online estimated progno- sis and the real outcome of these patients, in which we measured the three-year overall and disease free survivals in a follow up of three years; the same end-points were estimated on a 10 year basis by the Adjuvant! Online program, using variables such as age, clinical stage, histological grade, lymph node involvement, immunohistochemical subtype and type of adjuvant therapy, just to find that the data somewhat follow the same pattern, with the only discrepant subgroup being women younger than 40 years.

\section{Methods}

The population was composed of women with previously diagnosed breast cancer which were followed in three Southern Brazilian institutions: The Mastology unit at the Family and Community Health Division of the Itajai's Valley University (UNIVALI), The oncology unit (UNACON) of the Marieta Konder Bornhausen Hospital and maternity, and at a private clinic (Clínica de Neoplasias Litoral), all located in the city of Itajaí, SC, Brazil. It is a retrospective cohort, with overall and disease free survivals in a three year follow up. We have revised 363 medical files dated between $01 / 01 / 2001$ to 31/05/2006.

Our inclusion criteria were: female gender, uni- or bilateral breast cancer with all the staging registered in the files, confirmation of diagnosis through pathological exam of the surgical specimen from the same time span as indicated above (i.e. 01/01/2001 a 31/05/2006). At the same time, all the specimens must have had the immunohistochemical study of estrogen and progesterone receptors, HER2 and Ki-67, with which they were sub-typed. The files that had incomplete data regarding the studied variables were

Tab. 1. Overall survival and disease free survival comparing the Adjuvant! Online and the observed in our cohort.

\begin{tabular}{lllll}
\hline & \multicolumn{3}{l}{ Overall survival (\%) } & \multicolumn{2}{l}{ Disease free survival (\%) } \\
$\mathbf{N}$ & Adjuvant! & Our cohort & Adjuvant! & Our cohort \\
214 & 65,20 & 92,52 & 57,41 & 78,50 \\
\hline
\end{tabular}

excluded from final analysis. From the initial 363 medical files, 310 had the date of diagnosis ranging from 2001 to 2006 (the time frame of our study). We have excluded 57 files for subsequent follow-up loss and a further 39 for being in fact either advanced stage at the time of diagnosis or carcinoma in situ, which left us with 214 that were suitable according to our requirements.

For the estimation of relapse and death risks, we utilized the program Adjuvant! Online (8.0 version). It is necessary to enter the data entry of age, estrogen status, histological grade, size of tumor, number of committed lymph nodes and type of adjuvant chemotherapy or hormonal therapy.

As we did not have always available data of the size of tumor in centimeters and number of involved lymph nodes but instead the TNM staging, we considered that $\mathrm{T} 1$ is equivalent to tumors ranging from 0.1 to $1 \mathrm{~cm}$; T2 from 2.1 to $3 \mathrm{~cm}$; T3 or more equivalent to a tumor bigger than $5 \mathrm{~cm}$; NO is no lymph node involvement and $\mathrm{N} 1$ or more was considered as 1 to 3 involved lymph nodes. It was a rather rare situation though, with the wide majority of patients having precise data.

Every analyzed patient has a result in percentage corresponding to overall and disease free survivals estimated in 10 years.

For analysis, the variable of age, clinical stage, histological grade, lymph node status, immunohistochemical subtype and type of adjuvant therapy performed were considered. These variables were obtained according to observed median of control groups, and compared to the median of overall and disease free survivals registered in the follow-up.

The data were exposed and analyzed with descriptive statistical methods. This work was submitted and approved by the ethical research committee at the UNIVALI. The data were obtained for this study from a post-hoc analysis.

\section{Results}

The DFS and OS rates observed in the sample and estimated by the program demonstrated clear correspondence, 
Tab. 2. Comparison of the overall and disease free survivals between the Adjuvant! Online and the ones observed in our cohort according to the variables.

\begin{tabular}{|c|c|c|c|c|c|c|}
\hline & & \multirow[b]{2}{*}{$n$} & \multicolumn{2}{|c|}{ Overall survival (\%) } & \multicolumn{2}{|c|}{ Disease free survival (\%) } \\
\hline & & & Adjuvant! & Our cohort & Adjuvant! & Our cohort \\
\hline \multirow[t]{3}{*}{ age } & $<40$ & 9 & 77,99 & 88,89 & 70,96 & 55,56 \\
\hline & $40-60$ & 116 & 72,88 & 93,10 & 65,11 & 81,90 \\
\hline & $>60$ & 89 & 53,89 & 92,13 & 46,09 & 76,40 \\
\hline \multirow[t]{3}{*}{ stage } & 1 & 34 & 81,88 & 97,06 & 74,99 & 88,24 \\
\hline & II & 121 & 67,25 & 93,39 & 59,19 & 80,17 \\
\hline & III & 59 & 51,37 & 88,14 & 43,40 & 69,49 \\
\hline \multirow[t]{4}{*}{ grade } & 1 & 7 & 80,49 & 85,71 & 74,36 & 85,71 \\
\hline & II & 103 & 68,99 & 94,17 & 61,08 & 82,52 \\
\hline & III & 55 & 62,81 & 96,36 & 55,01 & 74,55 \\
\hline & indef. & 49 & 57,72 & 85,71 & 49,92 & 73,47 \\
\hline \multirow[t]{2}{*}{ lymph node status } & positive & 89 & 55,13 & 87,64 & 47,09 & 70,79 \\
\hline & negative & 125 & 72,36 & 96,00 & 64,67 & 84,00 \\
\hline \multirow[t]{4}{*}{ IHC subtype } & luminal A & 116 & 68,64 & 93,97 & 59,88 & 86,21 \\
\hline & luminal B & 40 & 69,69 & 95,00 & 61,18 & 72,50 \\
\hline & HER2+ & 14 & 52,52 & 92,86 & 47,00 & 78,57 \\
\hline & triple-negative & 44 & 56,08 & 86,36 & 50,61 & 63,64 \\
\hline \multirow[t]{3}{*}{ treatment } & $\mathrm{HT}$ & 29 & 60,20 & 96,55 & 51,67 & 89,66 \\
\hline & QT & 47 & 54,86 & 76,60 & 49,64 & 53,19 \\
\hline & $\mathrm{HT}+\mathrm{QT}$ & 132 & 71,33 & 96,97 & 62,93 & 85,61 \\
\hline
\end{tabular}

trailing beneath the same pattern, with the best rates being observed in the "real" group due to shorter follow-up interval (3 versus 10 years). In spite of this major bias, it is important to pinpoint that the majority of the relapse and death events occurred during the first three years, tending to stabilize at the 3 to 10 years of follow-up interval [11]. The only group that demonstrated lesser DFS in relation with the estimated prognosis was group of patients younger than 40, in spite of the shorter follow-up. Considering the clinical poor prognosis in this subgroup of patients, it is possible that the internet tool underestimates the aggressiveness of the breast cancer tumors in young women. The results are shown in Tab. 1 and Tab. 2.

\section{Discussion}

To our knowledge, this is the first paper to study the validity of the Adjuvant! On line tool in a Latin American population, even though this population is largely composed of women of European ancestry.
It has already been suggested by a large study that patients under 40 not only have a poor prognosis but also appear to be biologically distinct beyond subtype distribution [12].

Our study shows interesting trends in breast cancer survival, even though the number of patients accrued may not be enough to have full external validity.

We conclude that the OS and DFS rates in our sample compared to the one calculated by the Adjuvant! Online program display general agreement, following the same pattern when considering different periods of follow-up (much longer in the internet tool). The only group which had poor concordance status was the group of younger patients (i.e. under 40), even though it was the least represented group in our sample. Nevertheless, it can be strongly suggested that the program underestimates the usually very bad prognosis in these cases, as broadly documented in medical literature [13-15].

We plan to keep on the follow-up of these patients until we are able to reach a median of ten years, hence equalizing the follow up periods in order to have a better view of the clinical validation of Adjuvant! Online in Latin American women. We also look forward to updated versions of the program, including the molecular subtypes and new overall and disease free survival changing drugs, such as trastuzumab [16].

\section{References}

1. Baselga J, Cortés J, Kim SB et al. CLEOPATRA Study Group. Pertuzumab plus trastuzumab plus docetaxel for metastatic breast cancer. N Engl J Med 2012; 366(2): 109-119.

2. Geyer CE, Forster J, Lindquist $D$ et al. Lapatinib plus capecitabine for HER2-positive advanced breast cancer. N Engl J Med 2006; 355(26): 2733-2743.

3. Verma S, Miles D, Gianni L et al. EMILIA Study Group. Trastuzumab emtansine for HER2-positive advanced breast cancer. N Engl J Med 2012; 367(19): 1783-1791

4. DeSantis C, Siegel R, Bandi P et al. Breast cancer statistics 2011. CA Cancer J Clin 2011; 61 (6): 409-418.

5. Cuzick J, Sestak I, Baum M et al. Effect of anastrozole and tamoxifen as adjuvant treatment for early-stage breast cancer: 10-year analysis of the ATAC trial. Lancet Oncol 2010; 11(12): 1135-1141.

6. McDermott U, Downing JR, Stratton MR. Genomics and the continuum of cancer care. N Engl J Med 2011; 364(4): 340-350. 
7. Sotiriou C, Pusztai L. Gene-expression signatures in breast cancer. N Engl J Med 2009; 360(8): 790-800.

8. Cassol L, Silveira GM, Zelmanowicz A et al. Basal-like immunophenotype markers and prognosis in early breast cancer. Tumori 2010; 96(6): 966-970.

9. Ravdin PM, Siminoff LA, Davis GJ et al. Computer program to assist in making decisions about adjuvant therapy for women with early breast cancer. J Clin Oncol 2001; 19(4): 980-991.

10. Olivotto IA, Bajdik CD, Ravdin PM et al. Population-based validation of the prognostic model ADJUVANT! for early breast cancer. J Clin Oncol 2005 23(12): 2716-2725.
11. Abdulkarim BS, Cuartero J, Hanson J et al. Increased risk of locoregional recurrence for women with T1-2NO triple-negative breast cancer treated with modified radical mastectomy without adjuvant radiation therapy compared with breast-conserving therapy. J Clin Oncol 2011 29(21): 2852-2858

12. Azim HA Jr, Michiels S, Bedard PL et al. Elucidating prognosis and biology of breast cancer arising in young women using gene expression profiling. Clin Cancer Res 2012; 18(5): 1341-1351.

13. Cancello G, Maisonneuve P, Rotmensz N et al. Prognosis and adjuvant treatment effects in selected breast cancer subtypes of very young women ( $<35$ years) with operable breast cancer. Ann Oncol 2010; 21(10): 1974-1981.
14. Colleoni M, Rotmensz N, Peruzzotti G et al. Role of endocrine responsiveness and adjuvant therapy in very young women (below 35 years) with operable breast cancer and node negative disease. Ann Oncol 2006; 17(10): 1497-1503.

15. Tang J, Wu CC, Xie ZM et al. Comparison of Clinical Features and Treatment Outcome of Breast Cancers in Young and Elderly Chinese Patients. Breast Care (Basel) 2011; 6(6): 435-440.

16. Piccart-Gebhart MJ, Procter M, Leyland-Jones B et al. Herceptin Adjuvant (HERA) Trial Study Team. Trastuzumab after adjuvant chemotherapy in HER2-positive breast cancer. N Engl J Med 2005; 353(16): 1659-1672. 